\title{
Exotic SNaILS Dominate Nitrogen ANd CARbon CyCling in a Highly Productive Stream
}

\author{
ROBERT O. HALL, JR.* + DEPARTMENT OF ZOOLOGY AND PHYSIOLOGY \\ UNIVERSITY OF WYOMING $\uparrow$ LARAMIE
JENNIFER L. TANK $\uparrow$ DEPARTMENT OF BIOLOGICAL SCIENCES UNIVERSITY OF NOTRE DAME $\uparrow$ NOTRE DAME $\uparrow \mathrm{IN}$ \\ MARK F. DYBDAHL + SCHOOL OF BIOLOGICAL SCIENCES \\ WASHINGTON STATE UNIVERSITY $\uparrow$ PULLMAN
}

\begin{abstract}
$\uparrow \quad$ ABSTRACT
Individual animal species can impact ecosystem processes, but few exotic animal species have demonstrated ecosystem-scale impacts, in spite of large population sizes. We combined wholestream measures of carbon and nitrogen fluxes with rates of consumption and ammonium excretion to show that an exotic freshwater snail, Potamopyrgus antipodarum, dominated carbon and nitrogen fluxes in a highly productive stream. Exotic snails consumed $75 \%$ of gross primary productivity, and their excretion accounted for two-thirds of ammonium demand. These large fluxes were due to high snail biomass rather than high per-biomass rates of excretion or consumption. This exotic snail may dramatically alter ecosystem function in rivers, with potential consequences for food web structure and element transport.
\end{abstract}

Individual animals species can alter ecosystem functioning, such as nutrient cycling and storage, by directly altering carbon or nitrogen flux through grazing or excretion of ammonium (Grimm 1988, Frank et al. 1997, Vanni 2002), or indirectly via predation (e.g. Schindler et al. 1997). Despite numerous examples linking animal species with ecosystem processes, e.g., nutrient fluxes, there have been only a few examples showing how exotic animals may affect ecosystem processes or overall functions (Strayer et al. 1999, Lovett et al. 2003). Exotic animals might provide a model system for examining single-species impacts on ecosystem processes for several reasons. There are potentially strong ecosystem-scale impacts from exotic animals because they sometimes can dominate invaded ecosystems in terms of biomass. They also might bring a new trait to the invaded ecosystem, e.g. a generalist predator. However, there are few generalizations about how an exotic animal will impact native ecosystems, in spite of many impact studies which are mostly at the population or community level (Parker et al. 1999, Byers et al. 2002).

Parker et al. (1999) presented a framework for considering exotic species impact as: $I=$ $R \times A \times E$, where $R=$ range (unit area), $A=$ biomass per unit area, and $E=$ per-biomass impact. Localscale impact can be determined by either high biomass (e.g. Strayer et al.1990) or by high perbiomass impact relative to native species, which may include an exotic species that brings a novel trait (Vitousek 1990, Byers 2000). Despite this framework, we do not know the degree to which either high biomass or high per-biomass impact contributes to overall ecosystem-scale impact by invading animals. Separating these two will allow better prediction of impacts in that we can focus research and management on understanding either specific traits or potential maximum biomass of invaders.

We studied the role of the exotic New Zealand mud snail, Potamopyrgus antipodarum, on 
carbon $(\mathbb{C})$ and nitrogen $(\mathrm{N})$ fluxes in Polecat Creek, Wyoming (Fig. 1). We scaled their per-biomass rates of organic matter consumption and ammonium excretion by smails to whole-stream rates in an 800 -m reach. We compared these scaled estimates with whole-stream measures of $\mathrm{C}$-fixation and $\mathrm{N}$ cycling to estimate the snail's contribution to stream $\mathbf{C}$ and $\mathrm{N}$ cycling (Grimm 1988, Vanni 2002). Because we scaled the impact of snails by multiplying perbiomass rates by snail biomass, we were able to estimate the degree to which high biomass or high per-biomass rates contributed to the dominance of $\mathrm{N}$ and $\mathbf{C}$ fluxes in this stream. We compared both the per biomass rates and dominance of ecosystem $\mathrm{N}$ fluxes by Potamopyrgus with literature values for other freshwater invertebrates.

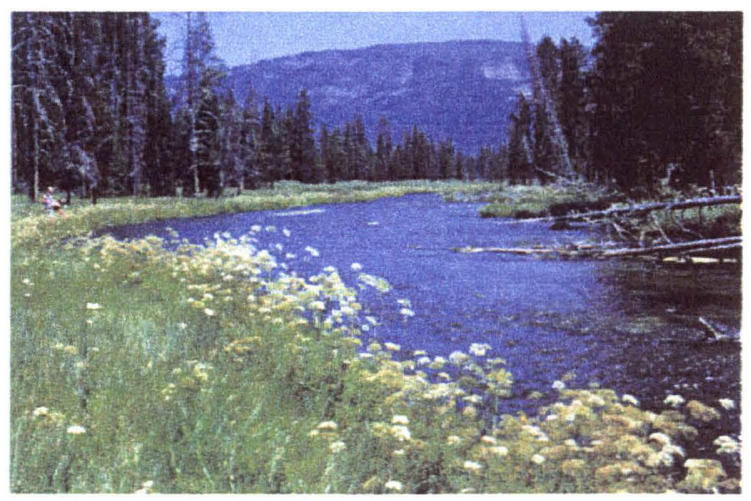

Figure 1. Polecat Creek, located in the John D. Rockefeller National Parkway, Wyoming

\section{Study System}

Potamopyrgus antipodarum is an herbivore/detritivore that invaded rivers in Yellowstone National Park in 1994 and has rapidly spread within and near the Park (Fig. 2). Potamopyrgus is mative to lakes and streams in New Zealand where females may be sexual or parthenogenetic clones (Dybdahl and Lively 1995), but exotic populations in North America are allfemale clones (MF Dybdahl unpublished data). It has achieved high densities, 20,000 - 500,000 snails $/ \mathrm{m}^{2}$ (RO Hall unpublished data), in all geothermal spring streams in and around the Park; hence, there are mo suitable reference sites by which to compare invaded and uninvaded warm spring streams. Our study site, Polecat Creek, is a geothermal spring stream that flows through the southern area of Yellowstone National Park and John D. Rockefeller National Parkway, in northwest Wyoming, USA. We used an 800-m reach $\sim 2 \mathrm{~km}$ upstream of Flagg Ranch Resort. Strearn temperature was warm and stable (average
January 2001 temperature was $14.4^{\circ} \mathrm{C}$; average July 2001 temperature was $23.5^{\circ} \mathrm{C}$ ). The stream bottom was carpeted by fillamentous algae and vascular plants, with few open areas of cobble and gravel. Polecat Creek is N-limited (JL Tank and RO Hall, unpublished data). Average channel width was $16 \mathrm{~m}$ and summer discharge was $1.3-1.9 \mathrm{~m}^{3} / \mathrm{s}$.

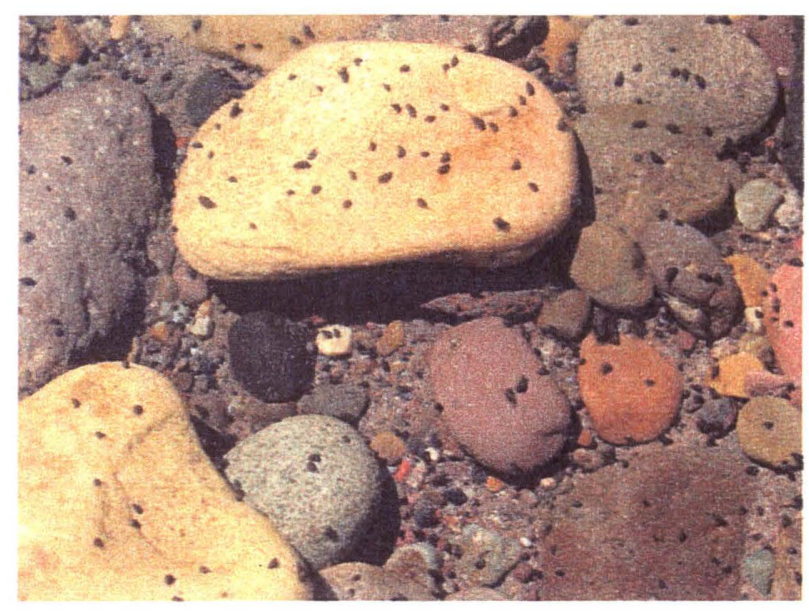

Figure 2. Example of Potamopyrugs antipodarium easily visible on cobbles, in the nearby Snake River in Yellowstone National Park

\section{$\downarrow$ METHODS}

We measured ammonium $\left(\mathrm{NH}_{4}{ }^{+}\right)$uptake by benthic algae and microbes in Polecat Creek and compared this uptake with scaled rates of $\mathrm{NH}_{4}^{+}$ excretion by snails. First, we estimated $\mathrm{NH}_{4}{ }^{+}$uptake length, the average distance traveled by a $\mathrm{NH}_{4}{ }^{+}$ion in stream water prior to incorporation by benthic microbes (Newbold et al. 1981). We added a small amount of $\mathrm{NH}_{4}{ }^{+}(12 \mu \mathrm{gN} / \mathrm{L})$ for $2 \mathrm{~h}$ and measured its concentration decline downstream. We calculated $\mathrm{NH}_{4}{ }^{+}$ uptake length as:

$$
\ln N_{x}=\ln N_{0}-a x,
$$

where $N_{x}$ and $N_{0}$ are dilution-corrected $\mathrm{NH}_{4}^{+}$ concentrations at $x \mathrm{~m}$ downstream from the addition site $(0 \mathrm{~m}), a$ is a per-meter uptake rate $(1 / \mathrm{m})$, and uptake length, is $1 / a$ (Newbold et al. 1981). Uptake length will vary with water depth and velocity; thus fast, deep streams will carry a nutrient molecule farther before it has the opportunity to contact the stream bed. Such hydrologic and geomorphic controls on uptake length confound our ability to compare streams with respect to biological nutrient demand (Davis and Minshall 1999). Thus, to compare nutrient demand among streams and years 
with varying discharge we calculated a $\mathrm{NH}_{4}{ }^{+}$uptake velocity $\left(V_{\mathrm{f}}\right)$ as

$V_{\mathrm{f}}(\mathrm{m} / \mathrm{min})=v d a$

where $d$ is stream depth (m) and $v$ is water velocity $(\mathrm{m} / \mathrm{min})$, and is conceptually considered as the demand for ammonium relative to its water-column concentration. Lastly, we calculated area-specific $\mathrm{NH}_{4}^{+}$uptake, $U$ as

\section{$U\left(\mathrm{mg} \mathrm{N} \mathrm{m}{ }^{-2} \mathrm{~h}^{-1}\right)=V_{\mathrm{f}} \times N_{\mathrm{a}}$}

(Newbold et al. 1981), where $N_{\mathrm{a}}$ is ambient $\mathrm{NH}_{4}^{+}$ averaged from 16 pre-addition samples. We measured nitrate $\left(\mathrm{NO}_{3}^{-}\right)$uptake using the same methods.

We quantified whole-stream gross primary production (GPP) and community respiration (CR), measured as oxygen production and consumption, and compared these metabolism rates with organic matter ingestion by snails. We used the open-channel diel oxygen method (Odum 1956, Hall and Tank 2003), which integrates GPP and CR over the $800-\mathrm{m}$ stream reach by budgeting fluxes of oxygen based on upstream inputs, downstream losses, exchange with the atmosphere, and metabolism. To estimate fluxes of oxygen from upstream and out to downstream, we recorded dissolved oxygen concentrations and stream temperature continuously throughout two nights and one day at the top and bottom of the $800-\mathrm{m}$ reach using recording oxygen sensors (Hall and Tank 2003). Exchange of dissolved oxygen with the atmosphere was estimated by measuring the rate of loss of sulfur hexafluoride, a tracer gas that exchanges at a rate proportional to oxygen (Hall and Tank 2003). Metabolism was thus estimated by difference; CR was measured as metabolism at night, whereas net-ecosystem metabolism, (i.e. GPP-CR), was measured during the day. We converted oxygen flux to carbon by assuming that for every mole of $\mathrm{O}_{2}$ produced a mole of $\mathrm{C}$ is fixed, and that organic matter contained $50 \%$ carbon.

We measured ingestion rates of organic matter by first estimating egestion rates of organic matter (as fecal pellets), and then converting to ingestion rates by dividing egestion rate by (1assimilation efficiency). We assumed an assimilation efficiency of 0.3 for invertebrates consuming algae (Hall et al. 2001). Egestion was measured by incubating snails in filtered water for $1 \mathrm{~h}$, and collecting and weighing organic matter of feces. We measured $\mathrm{C}: \mathrm{N}$ of fecal pellets and snails with a Carlo-Erba CN analyzer to convert egestion as organic matter to an $\mathrm{N}$ egestion rate. Ingestion rate of nitrogen was calculated differently than for organic matter by summing egestion, excretion, and secondary production of $\mathrm{N}$.

To estimate the rate at which snails recycled assimilated $\mathrm{N}$ back to the water column, we measured their $\mathrm{NH}_{4}^{+}$excretion rate by measuring $\mathrm{NH}_{4}^{+}$ production of 7-21 snails incubated in 20-ml vials with filtered stream water in the field for $1 \mathrm{~h}$. Following the incubation we filtered water samples and immediately analyzed them for $\mathrm{NH}_{4}{ }^{+}$. We converted $\mathrm{NH}_{4}^{+}$production to per-biomass excretion rates, which we scaled to stream bottom area by multiplying by snail biomass.

Snail and native invertebrate biomass was measured in July and August 2001 by collecting 6 benthic samples on each date using a 15.2-cm diameter stovepipe corer. All taxa were counted and measured to estimate mass using length-mass regressions. Secondary production of mud snails was estimated by multiplying snail biomass by perbiomass growth rates measured in the field (MF Dybdahl and RO Hall, unpublished data). To estimate the combined biomass of the primary producers, we sorted, weighed, and ashed the macroalgal and vascular plant material from each of the cores and estimated $\mathrm{C}$ and $\mathrm{N}$ content of primary producers as for snails.

\section{RESULTS AND DISCUSSION}

Potamopyrgus had high densities and biomass during July and August 2001 (Table 1). Snails dominated the invertebrate assemblage during these months, while native invertebrate biomass constituted only $3 \%$ of total biomass.

Table1. Mean Potamopyrgus antipodarum abundance, biomass, secondary production, and scaled excretion and egestion fluxes relative to native invertebrates in Polecat Creek, Wyoming, during July and August 2001

\begin{tabular}{|c|c|c|c|c|c|c|}
\hline & Abundance & Biomass & Production & Excretion & Egestion & \\
\hline & ind. $/ \mathrm{m}^{2}$ & $\mathrm{~g} \mathrm{AFDM} / \mathrm{m}$ & $\mathrm{mg} \mathrm{AFDM} \mathrm{m} \mathrm{m}^{-2} \mathrm{~d}^{-1}$ & $\mathrm{mg} \mathrm{N} \mathrm{m}^{-2} \mathrm{~h}^{-1}$ & g AFDM m $^{.2} \mathrm{~d}^{\circ}$ & $\mathrm{mg} \mathrm{N} \mathrm{m}^{-2} \mathrm{~d}^{-1}$ \\
\hline Potamopyrgus & 483,000 & 34.5 & 1490 & 7.8 & 4.1 & 190 \\
\hline $\begin{array}{l}\text { Native primary } \\
\text { consumer taxa }\end{array}$ & 950 & 0.95 & 41 & $0.17^{*}$ & ne† & $8.7^{*}$ \\
\hline
\end{tabular}

* Rates estimated based on Grimm (1988)

$\dagger$ rate not estimated

Gross primary production (GPP) and community respiration were consistently high in Polecat Creek (Table 2). In fact, rates of GPP from Polecat Creek were higher than all other wholestream measurements reviewed by Wetzel (2001), and were higher than seven of eight streams in an inter-biome study in North America (Mulholland et al. 2001). Biomass of macroalgal and vascular 
primary producers, which likely supports a productive attached microalgal assemblage, was also large (170 g AFDM / m). Despite high primary productivity in Polecat Creek, Potamopyrgus consumed nearly all of primary production. Perbiomass Potamopyrgus egestion rates averaged $0.12 / \mathrm{d}$ and ranged from $0.09 / \mathrm{d}-0.18 / \mathrm{d}$, which converted to an ingestion rate of $0.17 / \mathrm{d}$. Multiplying per biomass ingestion rate by snail biomass gave an area-specific ingestion rate of $5.9 \mathrm{~g} \mathrm{AFDM} \mathrm{m}^{-2} \mathrm{~d}^{-1}$ which was about $75 \%$ of daily GPP (average $=7.9 \mathrm{~g}$ AFDM m $\mathrm{m}^{-2} \mathrm{~d}^{-1}$ ) (Table 2). This consumption rate of GPP may be overestimated because algae respire some fraction (usually assumed to be 50\%) of GPP for their own metabolism and error in measuring snail biomass and ingestion rate may contribute to this overestimation. However, we can conclude that snails consumed a large proportion of daily primary production.

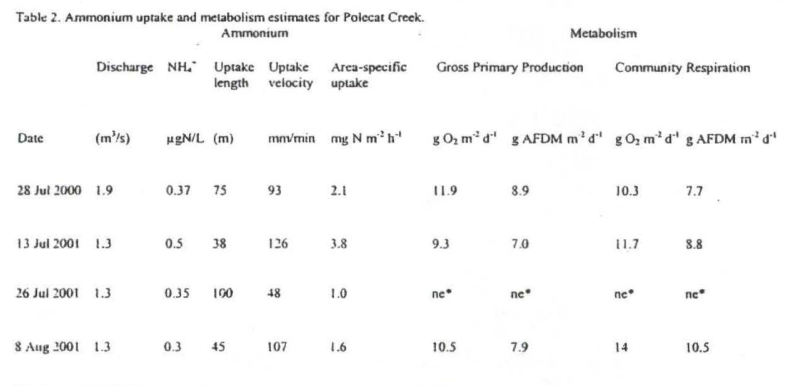

We compared snail $\mathrm{NH}_{4}^{+}$excretion to both the measured net $\mathrm{NH}_{4}{ }^{+}$uptake of from water column to benthos and the estimated gross $\mathrm{NH}_{4}{ }^{+}$uptake calculated from primary production measurements. Nitrogen cycling was rapid in Polecat Creek. Ammonium concentrations were extremely low and $\mathrm{NH}_{4}^{+}$uptake lengths were short $($mean $=65 \mathrm{~m}$ ) (Table 2) and residence time of $\mathrm{NH}_{4}{ }^{+}$in the water column averaged only $1.7 \mathrm{~min}$. Ammonium uptake velocities were high (Table 2), among the highest previously published for any aquatic ecosystem including seagrass beds and coral reefs (Thomas et al. 2000). The only $\mathrm{NH}_{4}{ }^{+}$uptake velocity higher than Polecat Creek was a section of the Kuparuk River in Alaska $\left(V_{\mathrm{f}}=120 \mathrm{~mm} \mathrm{~min}^{-1}\right)$ that has been experimentally fertilized with phosphorus since 1983 (Wollheim et al. 2001). Despite this high demand for $\mathrm{NH}_{4}^{+}$, area-specific uptake of $\mathrm{NH}_{4}{ }^{+}$was average because of the extremely low $\mathrm{NH}_{4}{ }^{+}$concentration (Table 2). Because nitrate uptake lengths were 5-17 times longer than $\mathrm{NH}_{4}{ }^{+}$uptake lengths and nitrate concentrations were $<1 \mu \mathrm{g} / \mathrm{L}$, nitrate was not likely a substantial source of $\mathrm{N}$ to the benthic assemblage relative to $\mathrm{NH}_{4}{ }^{+}$. It is possible that much of the demand for $\mathrm{NH}_{4}{ }^{+}$was met by recycling within the thick algal/vascular plant mat in this stream. We can roughly estimate net demand for nitrogen based on estimated primary production (Hall and Tank 2003). Assuming net primary production (NPP) is $50 \%$ of GPP, and converting to $\mathrm{O}_{2}$ evolution to $\mathrm{C}$ fixation, we estimate NPP to be $2.0 \mathrm{~g} \mathrm{C} \mathrm{m}^{-2} \mathrm{~d}^{-1}$. Given $14 \mathrm{~h}$ of daylight, our calculated hourly rate of $\mathrm{C}$ fixation is $0.14 \mathrm{~g} \mathrm{C} \mathrm{m}^{-2} \mathrm{~h}^{-1}$. Nitrogen uptake rate should be stoichiometrically related to $\mathrm{C}$ fixation and measured molar $\mathrm{C} / \mathrm{N}$ ratio for filamentous algae and epiphytes was 14; therefore, $N$ uptake should be $1 / 14$ of NPP. Given these assumptions, we predict that $\mathrm{NH}_{4}^{+}$uptake should be $12 \mathrm{mg} \mathrm{N} \mathrm{m}^{-2} \mathrm{~h}^{-1}$ suggesting that recycling of $\mathrm{NH}_{4}^{+}$within the algal mat was 5 times higher than the flux from the water column to the algal mat.

Snail excretion was a large fraction of ecosystem $\mathrm{NH}_{4}{ }^{+}$demand. Excretion rates of $\mathrm{NH}_{4}{ }^{+}$by Potamopyrgus decreased with increasing snail size and ranged from 0.1-0.46 $\mu \mathrm{g} \mathrm{N} \mathrm{mg} \mathrm{AFDM}^{-1} \mathrm{~h}^{-1}$ resulting in a biomass-weighted mean excretion rate of $0.23 \mu \mathrm{g} \mathrm{N}$ mg AFDM $^{-1} \mathrm{~h}^{-1}$ (Table 1). To estimate area-specific excretion fluxes for the entire stream bed we multiplied excretion rate by snail biomass. Snails excreted $7.8 \mathrm{mg} \mathrm{N} \mathrm{m}^{-2} \mathrm{~h}^{-1}$ (Table 1) which was almost 4 times higher than the average $\mathrm{NH}_{4}{ }^{+}$flux from the water column to the benthos of $2.1 \mathrm{mg} \mathrm{N} \mathrm{m}^{-}$ ${ }^{2} \mathrm{~h}^{-1}$. However, given our predicted gross $\mathrm{NH}_{4}^{+}$ uptake of $12 \mathrm{mg} \mathrm{N} \mathrm{m}^{-2} \mathrm{~h}^{-1}$ within the algal mat, then Potamopyrgus excreted about $65 \%$ of the estimated total $\mathrm{NH}_{4}^{+}$demand by microbes and plants.

Using these fluxes we can create a nitrogen box model for Polecat Creek that includes the exotic snail, Potamopyrgus (Fig. 3). The transfer of nitrogen from benthic primary producers and detritus to the exotic snail represents the largest flux of $\mathrm{N}$ in the stream and was much higher than the flux to native primary consumers. Potamopyrgus dominated fluxes of $\mathrm{C}$ and $\mathrm{N}$, despite the fact that Polecat Creek had high rates of primary production and tight cycling of nitrogen. In effect, snails were one of the largest components in the Polecat Creek ecosystem; standing crop of snail $\mathrm{N}$ equaled benthic plant $\mathrm{N}$, they consumed $75 \%$ of GPP, and they were responsible for most of the $\mathrm{NH}_{4}{ }^{+}$regeneration in this stream.

Did snails dominate these fluxes because they had high biomass or because of their high perbiomass rates of $\mathrm{N}$ ingestion and excretion? Excretion rates were in the middle of the range found for invertebrates in a desert stream (Grimm 1988). Another exotic species, zebra mussels, has slightly lower excretion rates (0.045-0.32 $\mu \mathrm{g} \mathrm{N}$ mg AFDM $^{-1}$ 
$\mathrm{h}^{-1}$ ) (Arnott and Vanni 1996), which are also within the range reported by Grimm (1988). Per-biomass consumption rates were nearly 2 times lower than for primary consumers in two temperate forest streams (0.31-0.32/d) (Hall et al. 2001), and about 12 times lower than periphyton removal predicted by Cattaneo and Mousseau (1995). We conclude that Potamopyrgus had excretion and consumption rates equivalent or lower than other animals; therefore, it dominated the $\mathrm{N}$ cycle in Polecat Creek because of its high biomass, not because it had particularly high per-biomass rates.

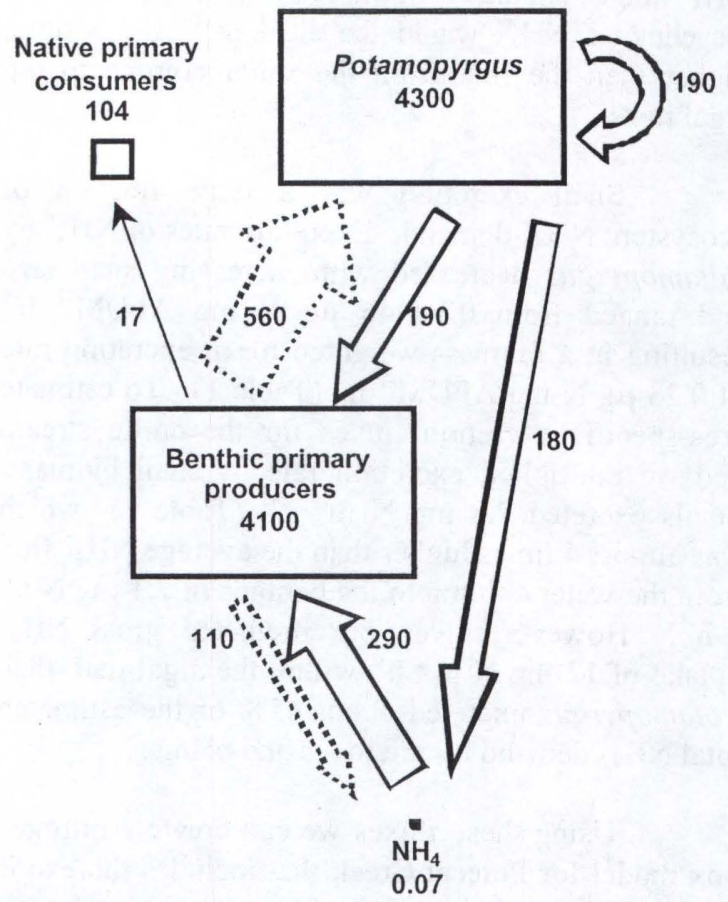

Figure 3. Stocks and fluxes of nitrogen in Polecat Creek. Stocks of $\mathrm{N}\left(\mathrm{mg} \mathrm{N} \mathrm{m}^{-2}\right)$ are shown with boxes, and fluxes of $\mathrm{N}\left(\mathrm{mg} \mathrm{N} \mathrm{m}^{-2}\right.$ $\mathrm{d}^{-1}$ ) are shown with arrows. Box area and arrow width are proportional to these values. The circular arrow on the Potamopyrgus box represents their secondary production. Estimate of native invertebrate consumption of $\mathrm{N}$ was based on Grimm (1988). The flux from $\mathrm{NH}^{4}$ to benthic algae and detritus includes an estimate of $50 \mathrm{mg} \mathrm{N} \mathrm{m}^{-2} \mathrm{~d}^{-1}$ from water and $240 \mathrm{mg} \mathrm{N}$ $\mathrm{m}^{-2} \mathrm{~d}^{-1}$ from within algal mat. Grey arrows are fluxes calculated by difference; regeneration of $\mathrm{NH}_{4}$ is calculated as the difference between efflux and influx, and consumption of $\mathrm{N}$ by Potamopygrus was calculated as the sum of egestion, excretion and production, which were all measured directly.

Are ecosystem processes dominated by animal-derived fluxes in other ecosystems? We had no suitable uninvaded site which to compare similar streams without Potamopyrgus, but it is possible to compare Potamopyrgus-derived fluxes with those by animals in other systems. Area-specific rates of $\mathrm{N}$ excretion from all types of freshwater animals averaged $1.9 \mathrm{mg} \mathrm{N} \mathrm{m}^{-2} \mathrm{~h}^{-1}$ (range 0.2-9.3) (Vanni
2002) which is on average lower than our estimate of $7.8 \mathrm{mg} \mathrm{N} \mathrm{m}^{-2} \mathrm{~h}^{-1}$; interestingly, the only value higher than ours was for exotic zebra mussels in Lake Erie (Arnott and Vanni 1996). Animal excretion can meet a substantial fraction of ecosystem $\mathrm{N}$ demand (mean $=25 \%$ range $0.5-70 \%$ ) (Vanni 2002); this mean value is lower than our estimated percentage of $65 \%$. High values in Vanni (2002) (near or above 50\%) were for entire animal assemblages, whereas in Polecat Creek the high proportion of ecosystem N demand met by animal excretion is from only one species. Potamopyrgus, relative to other animals, dominated flows of $\mathrm{N}$ and $\mathrm{C}$ in Polecat Creek, despite the fact that rates of primary production and $\mathrm{N}$ cycling were extremely high. The impacts of this invasion are similar to zebra mussel invasions in that one organism that achieves high biomass can dominate fluxes; e.g. zebra mussels can filter all of the water column in 1-4 days (Strayer 1999), which is analogous to our finding that Potamopyrgus can consume nearly all primary production. Even in terrestrial habitats, the exotic gypsy moth can accelerate $\mathrm{N}$ cycling in forests (Lovett et al. 2003), which we suggest is similar to impacts by Potamopyrgus given their high rates of $\mathrm{N}$ regeneration.

Potamopyrgus dominated $\mathrm{N}$ fluxes in Polecat Creek; thus, it has likely altered ecosystem functions of storage and fluxes of N. This snail will likely have community-level impacts beyond the direct interactions with native species because they have altered ecosystem functioning at the base of the food web (Vitousek 1990). Additionally, species that dominate ecosystem function in rivers may affect processes beyond the ecosystem by altering nutrient retention and export to downstream ecosystems.

\section{ACKNOWLEDGEMENTS}

Thanks to M. Baker, C. Crenshaw, S. Farhny, L. Harvey, J. Knouft, C. Louwers, M. Marshall, M. Rehman, L. Riley, J. Schaefer, J. Schaller, B. Shafer, and M. VanderLoop for help in the field and lab. H. Harlow at the University of Wyoming / National Park Service Research Station provided lab space and logistical support. B. Taylor, M. Marshall, L. Curry, B. Koch and K. Cerreto, R. Irwin, and two anonymous reviewers commented on the manuscript. Funding was provided by the University of Wyoming / National Park Service Research Station and NSF EPSCoR (ROH), Univ. of Illinois Research Board and University of Notre 
Dame Faculty Research Program (JLT), and NSF and Yellowstone National Park (MFD).

* Reprinted from Frontiers in Ecology and the Environment.

\section{$\downarrow$ Literature Cited}

Arnott, D.L., and M.J. Vanni. 1996. Nitrogen and phosphorus recycling by the zebra mussel (Dreissena polymorpha) in the western basin of Lake Erie. Can J Fish Aquat Sci 53:646-659.

Byers, J.E. 2000. Competition between two estuarine snails: implications for invasions of exotic species. Ecology 81:1225-1239.

Byers, J.E., S. Reichard, J.M. Randall, et al. 2002. Directing research to reduce the impacts of nonindigenous species. Cons Biol 16: 630640 .

Cattaneo, A., and B. Mousseau. 1995. Empirical analysis of the removal rate of periphyton by grazers. Oecologia 103: 249-264.

Davis, J.C., and G.W. Minshall. 1999. Nitrogen and phosphorus uptake in two Idaho (USA) headwater wilderness streams. Oecologia 19:247-255.

Dybdahl, M.F., and C.M. Lively. 1995. Diverse, endemic, and polyphyletic clones in mixed populations of a freshwater snail Potamopyrgus antipodarum. J Evol Biol. 8: 385-398.

Frank, D.A., S.J. McNaughton, and B.F. Tracy. 1997. The ecology of the earth's grazing ecosystems. Bioscience 48: 513-521.

Grimm, N.B. 1988. Role of macroinvertebrates in nitrogen dynamics of a desert stream. Ecology 69: 1884-1893.

Hall, R.O., G.E. Likens, and H.M. Malcom. 2001. Trophic basis of invertebrate production in two forest streams. JN Am Benthol Soc 20: 432-447.

Hall, R.O., and J.L. Tank. 2003. Ecosystem metabolism controls nitrogen uptake in streams in Grand Teton National Park, Wyoming. Limnol Oceanogr 48:1120-1128.
Lovett, G.M., L.M. Christenson, P.M. Groffman, et al. 2002. Insect defoliation and nitrogen cycling in forests. BioScience 52: 335-341.

Mulholland, P.J., C.S. Fellows, and J.L. Tank. et al. 2001. Inter-biome comparison of factors controlling stream metabolism. Freshw Biol 46: 1503-1517.

Newbold, J. D., J. W. Elwood, R.V. O 'Neill, a nd W. VanWinkle. 1981. Measuring nutrient spiraling in streams. Can $J$ Fish Aquat Sci 38: $860-863$.

Odum, H.T.. 1956. Primary production of flowing waters. Limnol Oceanogr 2: 85-97.

Parker, I.M., D. Simberloff, W.M. Lonsdale, et al. 1999. Impact: toward a framework for understanding the ecological effects of invaders. Biological Invasions 1: 3-19.

Schindler, DE, S.R. Carpenter, J.J. Cole, et al. 1997. Influence of food web structure on carbon exchange between lakes and the atmosphere. Science 277: 48-251.

Strayer, D.L., N.F. Caraco, J.J. Cole, et al. 1999. Transformation of freshwater ecosystems by bivalves. BioScience 49: 19-27.

Thomas, F.I.M., C.D. Cornelisen, and J.M. Zande. 2000. Effects of ammonium uptake and canopy morphology on ammonium uptake by seagrass communities. Ecology 81: 27042713.

Vanni, M.J. 2002. Nutrient cycling by animals in freshwater ecosystems. Annu Rev Ecol Syst 33: $341-370$.

Vitousek, P.M. 1990. Biological invasions and ecosystem processes: toward an integration of population and ecosystem studies. Oikos 57: 7-13.

Wetzel, R.G. 2001. Limnology. Third edition. Academic Press, San Diego.

Wollheim, W.M, B.J. Peterson, L.A. Deegan, et al. 2001. Influence of stream size on ammonium and suspended particulate nitrogen processing. Limnol Oceanogr 46:1-13 